\title{
Impact of Decentralized Decision Making on Transfer Prices Models in a Multidivisional Company
}

\author{
Jelena Demko-Rihter \\ Assistant Professor, University of Novi Sad, Faculty of Technical Sciences, Trg Dositeja Obradovica 6, 21000 \\ Novi Sad, Serbia, jciric@uns.ac.rs
}

Received (19.12.2018.); Revised (30.01.2019.); Accepted (19.02.2019.)

\begin{abstract}
Transfer prices are prices determined in the purchase and selling transactions between business segments or divisions within a company. Tax aspect and the management aspect of transfer prices are usually considered in the literature and praxis. Research in this paper is focused on the relation between the degree of autonomy of divisional managers by making decisions and the way of determining transfer prices in selling and purchase transactions between divisions of a company. The aim of this paper is to introduce problem of transfer pricing and to explain how decentralized decision making through the transfer pricing system affects short-run and long-run divisional and corporate performances. Research has been carried out on a small sample of multidivisional companies that operate in Serbia. The main hypothesis is not confirmed, unlike similar results of researches carried out earlier in developed economies. Spearman's rank correlation coefficient and Phi coefficient are used in this research, as well as nonparametric Mann Whitney test.
\end{abstract}

Key words: autonomy, decision making, divisions, performances, transfer prices

\section{INTRODUCTION}

Transfer prices are prices that one business segment or division charges to other business segment for the delivered goods or services. It is the same price as if an „arm's length" transaction had taken place between independent businesses [19]. They express the value of products and services of one division which should be delivered to other divisions within the same company. In the process of decision making transfer prices present important information input for divisional managers as well as top management. One of roles of transfer prices is to enable delimitation of responsibilities and efficiency between business segments and are also an important management tool that should contribute to the coherence of divisional and company interests [10].

The transfer pricing system is the process for distributing revenue generated through the final sale of products or services. The main principle is that the transfer price should be similar to the price that would be charged if the product or service were sold on external market or purchased from external supplier.

Transfer prices can also be an instrument for improving competitiveness if the company's management decides that one business segment will sell to another at the lowest price in order to become more competitive in comparison to the other market participants. As well as transfer prices should to be set at a level that maximizes company profits, they also need to be set in a way that is compliant with tax laws, allows performance evaluation of both divisions and staff/managers, and is fair and therefore motivational. The main hypothesis of this paper is that degree of divisional managers' autonomy by decision making has impact on transfer pricing model implemented in selling and purchase transactions between divisions within a company. The paper is structured as follows: after Introduction, Section 2 gives a general overview of the commonly used transfer prices models in literature and praxis; Section 3 encompasses the relation between divisional autonomy and transfer pricing; Section 4 presents research method and results. In the Section 5 are presented concluding remarks.

\section{LITERATURE REVIEW}

The issue of transfer prices has been discussed in literature by many authors since the beginning of the fifties' years of the $20^{\text {th }}$ century or even earlier having in mind that General Motors and Du Pont were pioneers in using transfer prices for evaluation of units in the 1920s. The early application of transfer pricing were actually designed to facilitate the evaluation of unit performance [9]. In the 1950s Hirshleifer had explained that optimal situation is equation of marginal costs of selling and buying divisions [7]. During the 1960s had been developing different mathematical programs for the solution of transfer pricing problem in the case of multiple internal sales transactions.

Ronen and Balachandran (1988) have considered transfer pricing problem and concluded that optimal situation occurs when buying division acts as a planner 
in relation to the selling division. Brown and Weida (1991) have explained that top management should be a planner. Banker and Datar (1992) have tried to develop a model that will prevent the co-operation of divisional managers who tend to increase divisional instead of corporate profit. In the last twenty years many authors have dealt with transfer pricing problems in the business of multinational companies which additionally complicates the problem. Lesser (1987) has showed that incorrectly determined transfer prices negatively affect the motivation of managers to reduce costs, especially if the transfer price is set by adding a fixed percentage to the existing costs. Cats-Baril, Gatti and Grinnell (1988) have advocated that the transfer pricing method should be changed over the time depending on the phase of the product life cycle. Galway (1990) has analyzed problem of implementation of the cost plus method especially if product is transferred through the numerous divisions. In that case the last division that sells transferred product on the external market will have to cover all the cost and become uncompetitive.Baldenius and Raichelstein have focused on managerial and tax objectives of transfer pricing. Kaplan and Atkinson have mostly dealt with the accounting approach of transfer prices. Harris, Kriebel and Raviv [6] have focused on the problem of resource allocation and found similarity to the transfer pricing problem. Many of scholars dealt with transfer pricing have recognized that a successful transfer pricing strategy should consider multiple criteria (objectives) such as overall profit, total market share, divisional autonomy, performance evaluation and utilized production capacity [18].

\subsection{Overview of the commonly implemented transfer pricing models}

In the literature are mostly presented and explained market, cost and negotiated transfer pricing methods, although Organization for Economic Cooperation and Development (OECD) has published guidelines for transfer prices and divided different methods into two main groups [15]:

- Transactiong group includes Comaprable Uncontrolled Price (CUP), cost-plus and resale price methods;

- The other methods include profit splits, transactional net margin methods and other approaches that are related to paritioning the profits from trading.

\section{Market transfer prices}

The market transfer price is an objective price by which the products would be sold on the market if business segments or division were independent companies. If the sales division effectively operates in comparison with competition, inter-divisional trade at market prices will contribute to the profit. In addition, an efficient buying division will be able to pay market transfer price to the selling division which otherwise would pay in case of external supply.
In case of a fully competitive market of market transfer prices will enable: 1) compliance of the objectives, 2) greater degree of motivation of management, 3) adequate evaluation of business segments' performances and 4) greater degree of autonomy of business segments [8, p. 942].

The application of market transfer prices increases the interest of the sales division for sale within the company, but it is also necessary to consider the impact on divisional and corporate profit as well as spare capacity of each division. If selling division has a spare capacity and no possibility for its alternative use the lower transfer price could be accepted. This price would cover at least variable costs and/or a small part of the fixed costs.

If the required quality of the product or service cannot be found on the external market or supply cannot be on time, priority will be given to supply from other division within a company [9, p. 109]. Usually there is hard to apply market-based transfer price for semi-finished products that should be further processed and are purchased from another division within a company. Inter-divisional trade can provide saving in packaging, delivery, advertising, avoiding bad and doubtful debts, eliminating different types of discounts as instrument of attracting buyers, etc.

Although market transfer price is highly recommended it is not always possible to apply it, because imperfect markets. The fact is that divisional managers in order to maximize short-term divisional interests, can act against short-term and long-term corporate interests. Therefore, the adoption of internal transfer pricing rules is recommended [1].

The OECD guidelines advocate whenever is possible the uncontrolled price (CUP) method, which uses either the market price or imputed market price. If there is no market price the suggestion is cost-plus method. Empirical research suggests that the cost transfer prices are mostly applied if realization is within a company that operates only on the domestic market. In case of business of multinational companies (MNC) market transfer prices are mostly applied in internal transfer of products and services between parts of MNC or between independent companies operating on markets abroad. Market transfer price has a priority because it respects the arm's length principle and corresponds to the CUP method recommended by OECD and the US Internal Revenue Service (IRS).

\section{Cost transfer prices}

Cost transfer prices are based on the production cost of the selling division. Transfer price can be determined on the basis of real or planned or standard costs as well as by adding a mark-up above the costs of selling division. Transfer price of selling division that includes total production costs mostly is not competitive with the price of external suppliers and might affect the decision of buying division to choose external supplier. This would have a negative impact on the profit of selling division, especially in case of spare capacity and no possibility of its alternative use [10, p.109]. Also for selling division is not acceptable price that covers only production costs 
and does not include mark-up. In this case the mark-up is realized only by division that is the last in the chain which means that sells to the external market $[17$, p.722].

An incentive to intra-company trade can be setting transfer prices on the base of costs plus usual mark-up of selling division. That price covers variable costs and part of fixed costs, as well as a mark-up as a motive and an incentive for selling to sell within a company. This should be considered in the context of spare capacities and possibility for its alternative use.

\section{Negotiated transfer prices}

Transfer prices determined by negotiation are defined by managers of selling and buying divisions on the basis of negotiations. If there is no possibility to apply a market or cost transfer prices managers of buying and selling divisions negotiate about prices. Negotiated transfer prices are generally below the usual market price that buying division would pay to an external supplier, but at the same time above the sum of the incremental and opportunity costs of the sales division.

Disadvantages of the negotiated transfer prices are that they require more time and effort of divisional managers in achieving mutually acceptable transfer prices. In those situtations are possible mutual conflicts of divisional managers and the outcome of the negotiations partly depends on the negotiating skills of divisional managers [9, p. 461].

\section{RELATION BETWEEN DIVISIONAL AUTONOMY AND TRANSFER PRICING MODELS}

Transfer pricing essentially impacts decision making and performance evaluation when divisional managers determine whether to supply externally on the market or internally within a decentralized company. Through the transfer prices system sale is allocated to the responsibility centres regarding arm's length principle which means that the transfer price of selling division should be equal to the external selling price and that purchasing price of buying division should be the same price that would be paid to an external supplier. Transfer prices have a dual mainly conflicting role. On the one hand they are important for decision-making and the production manager gains the information how much to produce, and the purchase manager gets the information how much and from whom to buy. On the other hand, transfer prices help the company's management to evaluate the performance of business segments (mostly profit and investment centres) and their management. The problem arises when divisional managers make decisions that misuse the performance of their responsibility centres.

However, the long-term interest of the divisions, but the whole company too, is the promotion of internal purchases and the reduction and control of production costs of the sales division and the increase of its efficiency in order to offer lower prices to the buying division. After determining the range of transfer price divisional manager should choose the easiest way of calculating it, bearing in mind the impact of transfer pricing on the divisional profit. More complicated ways of determining transfer prices require more time and increase costs. Since the transfer prices influence the profit of buying and selling division, from the aspect of internal reporting, responsibility accounting, motivation of divisional management and incentives, the transfer prices method and the profit allocation between divisions are very important. The level of decentralization and autonomy between or divisions also influence divisional performances, profit and resource allocation. One division could optimize own performances at the expense of corporate goals, e.g. when one division supplies externally although there are unused capacities in the production division. In the study conducted by Drury \& El-Shishini [4] has been found that divisional organizational structure is related to the process of decentralized decision-making. Divisional managers are mostly autonomous in terms of defining selling prices, selecting a sales market, defining a production mix and choosing a supplier (purchase from another division within a company or on external market).

Ezzamel and Hilton (1980) researched autonomy of divisional managers in 129 British companies and found the significant autonomy of divisional managers in making decisions on selling prices, terms of borrowing, advertising and purchase within a company or on external market. Unlike top management made decisions about capital investments and capital budgeting.

High level of autonomy is not recommended in production of unique parts of when intangibles are considerable factor, as well as when product design and development are an important aspect of the business.

Transfer prices can lead to conflict situations in terms of decision making and measuring divisional performances. Top management hasn't information they need to determine the transfer prices and are usually not familiar with all factors relevant to transfer pricing. Regardless of the possibility of the dysfunctional behaviour of divisional management, decisions on internal or external supply should nevertheless be made at lower organizational levels. If divisional managers would make decisions that could reduce divisional profit and rate of return of the profit or investment centre, this would also reduce bonuses of divisional managers that depend on the performances of their responsibility centres. Hence, divisional managers are primarily interested in the highest shortterm results of their accountability centres, not for the long-term profitability of the company. An alternative approach to solving the problem of transfer pricing in the context of agency theory is to establish an optimal contractual relationship between the principal and the agent, i.e. between the company's headquarters and the independent divisions, as a basis for disclosure of reliable and relevant information about divisional performances.

Having in mind that transfer price is an element of revenue of a selling divisions and at the same time element of cost of a buying division, transfer price 
affects the profitability of both divisions and their managers have a keen interest in a way of the price determination [9, p. 453].

If there is an external market for transfered products and if their prices are known market transfer prices could be applied which contributes to harmonization of the motives and interests of divisional management with the goals of the company, as well as maximizing the overall profit of the company.

The application of the cost method does not provide incentives for the divisional management to control and reduce costs, because costs are transfered from one division to another, which can threaten the process of measuring divisional performances achieved and at the same time cause conflict situations [10, p. 104]. The problem can be overcome if transfer price is determined on the basis of standard rather than real costs, in order to prevent the inefficient use of resources and transfer costs of unused capacity from selling to the buying division through transfer prices. Regardless of its imperfection cost method is mostly represented in practice due to simplicity of its application.

Method of negotiated transfer prices also has some deficiences, but is able to fulfill three main criteria or goals related to transfer pricing problem: congruence of divisional and corporate goals, (2) preserving of divisional autonomy and (3) accurate evaluation of realised performances.

Each divisional manager tends to maximize the difference between revenue and expenditure in his responsibility centre. This explains why transfer prices are the source of possible conflict situations. Transfer prices affect results of buying and selling divisions that further has impact on bonuses of divisional management which explains interest of divisional management to implement a particular transfer pricing model - market based, cost-based or negotiated. Implemented transfer pricing model affects reallocation of profits between divisions which are competitors for company's resources. Divisional managers have data on productivity of their area of responsibility but are not willing to disclosure those data to the top management without proper incentives, although top management needs those data for resource allocation. The effective use of resources and divisional productivity depends on the expenditures and transfer price that should cover expenditures and enables a mark-up of selling division. Therefore, the interest of divisional management is to enable the most efficient use of the allocated resources and the increase of productivity of its responsibility centre in order to increase divisional and corporate profit.

Different incentives should eliminate the dysfunctional behaviour of divisional managers and contribute to the harmonization of divisional and corporate goals. Most divisional managers are primarily oriented to maximizing short-term results of their area of responsibility as a basis for bonuses, which negatively affects long-term corporate performances. Therefore, top management often evaluates the performance of the divisional management and their areas of responsibility not only on the basis of financial but also non-financial indicators, in order to emphasize the importance of long-term, strategic orientation in the assessment of corporate performance.

Summarized financial indicators for the company as a whole are not useful to many employees and management at lower, operational level. This does not mean that financial indicators related to the reporting period are neglected, but more attention should be set on the present and future performance indicators as well investment in intangible assets, which is the basis for future growth.

It should be noticed that in a complex organization it is almost impossible to achieve perfect goal congruence between decentralized units and the overall corporation for any single performance measure. So that is usual that companies use balanced set of measures in order to harmonize divisional and corporate performances and goals [8, p.300].

It is also important to monitor and measure not only short-term operating results, but longer-term effects too, although they are harder to be measured. Investing in research and development (R\&D), human resources, quality control, plant design, maintenance, advertising and promotion generate expenditures and usually decrease short-term divisional performances. Because of that divisional managers are motivated to spend less on intangibles and maintenance, although it would have positive impact on long-term corporate goals and performances. Indicators of financial performances have some limitations regarding they deal with reporting period and historical cost concept while performance measures of divisional management should focus on future results as outcomes of present actions. Beside that financial performance indicators are usually shortterm based and this can lead to short-term orientation of divisional management. Hence divisional performance measures should be consistent with corporate performance measures used by financial market to evaluate results of a company. Top management and divisional management should be focused on the same performance indicators [2, 4].

Although some non-financial measures are difficult to measure objectively and in a short-term, they should be considered because of their considerable influence on the long-term performance. Some of them are product quality, morale of employees, output of professional services, innovation [8,p.301].

\section{RESULTS OF RESEARCH}

In this research is used a descriptive method which implies the use of different instruments and procedures for testing the hypothesis about the state and structure of the population that is the subject of the research. Correlation method research the connection between two or more variables and the intensity of their correlation in order to discover the relationship between the various attributes of population that has been tested. The causal-comparative method analyses the causal and consequential relations between phenomena and their attributes in uncontrolled conditions. 
Data are collected through the survey distributed to the 38 multidivisional companies which operate in Serbia, whose business is diversified and their divisions participate in inter-divisional transactions and there is a need for determining of transfer prices. Descriptive statistics is used for sample description. Regarding small sample non parametric tests are used. Spearman's rank correlation coefficient and Phi coefficient are used in this research. Mann Whitney is a nonparametric test used to compare outcomes between two independent groups, i.e. to test whether two samples are likely to derive from the same population. Pearson's chi-square test is used to discover if there is a relationship between two categorical variables. The Fisher Exact test is a test of significance that is used in the place of chi square test in 2 by 2 tables, especially in cases of small samples.

After choosing multidivisional companies the survey was sent per e-mail or delivered personally to respondents in selected companies; respondents fulfilled survey and sent it back and after that statistical processing and analysis of data has been done by using statistical software Statistica 7.

Hypothesis: The degree of divisional management autonomy in making decision affects the selection of transfer pricing model in selling and purchase transactions between divisions within a company.
By testing the relationship between variables, there is a marginally statistically significance between the independent variables of the autonomy of the divisional manager by defining the selling price $(\rho S=.350, p=$ 0.073 ) and decision on internal or external purchase or sale $(\rho S=.352, p=0.078)$ and dependent variable negotiated transfer pricing model.

There is also a marginally statistically significance between the independent variable of the divisional manager's autonomy in deciding on long-term borrowing and the dependent variable negotiated transfer pricing model $(\rho S=.379, p=0.056)$. It can be concluded that in companies where the negotiated transfer pricing model is applied, there is greater autonomy of divisional managers by deciding on internal or external purchase and sale and prices, as well as by deciding on long-term borrowing.

There is a marginally statistically significance between the independent variable of the divisional manager's autonomy in deciding on short-term borrowing and the dependent variable cost based transfer pricing model ( $\rho S=-.437, p=0.026)$. For all other decisions that indicate the degree of autonomy of divisional managers, testing by Spearman rank correlation coefficient there isn't marginally statistically significance related to transfer pricing model (market based, cost based or negotiated).These results are confirmed by nonparametric Mann-Whitney test.

Table 1. Determination of the relation between the degree of divisional management autonomy and the transfer pricing model using the Spearman's rank correlation coefficient

\begin{tabular}{|c|c|c|c|c|}
\hline \multicolumn{2}{|c|}{ Divisional management decisions } & \multirow{2}{*}{\begin{tabular}{|c|} 
Market based \\
-.182 \\
\end{tabular}} & \multirow{2}{*}{$\frac{\text { Negotiated }}{.350}$} & \multirow{2}{*}{$\frac{\text { Cost based }}{-.122}$} \\
\hline Determination of selling price & ps & & & \\
\hline & $\mathrm{p}$ & .364 & .073 & .544 \\
\hline & $\mathrm{N}$ & 27 & 27 & 27 \\
\hline \multirow[t]{3}{*}{ Determination of production and sales volume } & ps & .106 & .105 & -.250 \\
\hline & $\mathrm{p}$ & .607 & .609 & .218 \\
\hline & $\mathrm{N}$ & 26 & 26 & 26 \\
\hline \multirow[t]{3}{*}{ Capital budgeting } & ps & .103 & .313 & -.163 \\
\hline & $\mathrm{p}$ & .618 & .119 & .425 \\
\hline & $\mathrm{N}$ & 26 & 26 & 26 \\
\hline \multirow{3}{*}{$\begin{array}{c}\text { Deciding on internal or external selling and } \\
\text { purchase }\end{array}$} & $\rho s$ & -.241 & .352 & .074 \\
\hline & $p$ & .236 & .078 & .718 \\
\hline & $\mathrm{N}$ & 26 & 26 & 26 \\
\hline \multirow[t]{3}{*}{ Short-term borrowing } & $\rho s$ & .040 & .309 & $-.437^{\star}$ \\
\hline & $p$ & .845 & .124 & .026 \\
\hline & $\mathrm{N}$ & 26 & 26 & 26 \\
\hline \multirow[t]{3}{*}{ Long-term borrowing } & $\rho s$ & -.221 & .379 & -.162 \\
\hline & $p$ & .278 & .056 & .431 \\
\hline & $\mathrm{N}$ & 26 & 26 & 26 \\
\hline \multirow[t]{3}{*}{ Development of new products and services } & ps & -.028 & .254 & -.010 \\
\hline & $p$ & .891 & .211 & .959 \\
\hline & $\mathrm{N}$ & 26 & 26 & 26 \\
\hline \multirow[t]{3}{*}{ Contracting long-term deals with suppliers } & ps & .132 & .168 & -.201 \\
\hline & $\mathrm{p}$ & .522 & .411 & .324 \\
\hline & $\mathrm{N}$ & 26 & 26 & 26 \\
\hline \multirow{3}{*}{\begin{tabular}{|c|} 
In your company divisional managers \\
independently determine transfer pricing model by \\
defining selling price of products produced in their \\
responsibility centers
\end{tabular}} & ps & .032 & .143 & -.217 \\
\hline & $\mathrm{p}$ & .878 & .495 & .299 \\
\hline & $\mathrm{N}$ & 25 & 25 & 25 \\
\hline
\end{tabular}


Table 2. Nonparametric Mann-Whitney test of differences in the degree of divisional management autonomy regarding implementation of negotiated TP model

\begin{tabular}{|c|c|c|c|c|c|}
\hline Negotiated TP model & $\begin{array}{c}\text { Mann-Whitney } \\
U\end{array}$ & Wilcoxon W & $Z$ & $\begin{array}{l}\text { Asymptotic } \\
\text { significance } \\
\text { (2way-p) }\end{array}$ & $\begin{array}{c}\text { Exact } \\
\text { significance } \\
{\left[2^{*}(1-\text { way }\right.} \\
\text { significance/p)] }\end{array}$ \\
\hline $\begin{array}{l}\text { Determination of selling } \\
\text { price }\end{array}$ & 20.500 & 296.500 & -1.786 & .074 & $.082^{\mathrm{a}}$ \\
\hline $\begin{array}{c}\text { Determination of } \\
\text { production and sales } \\
\text { volume }\end{array}$ & 37.000 & 290.000 & -.526 & .599 & $.656^{a}$ \\
\hline Capital budgeting & 22.500 & 275.500 & -1.567 & .117 & $.130^{a}$ \\
\hline $\begin{array}{l}\text { Deciding on internal or } \\
\text { external selling and } \\
\text { purchase }\end{array}$ & 20.000 & 273.000 & -1.759 & .079 & $.096^{a}$ \\
\hline Short-term borrowing & 23.000 & 276.000 & -1.546 & .122 & $.150^{\mathrm{a}}$ \\
\hline Long-term borrowing & 18.500 & 271.500 & -1.897 & .058 & $.069^{a}$ \\
\hline $\begin{array}{l}\text { Development of new } \\
\text { products and services }\end{array}$ & 26.500 & 279.500 & -1.269 & .204 & $.223^{a}$ \\
\hline $\begin{array}{l}\text { Contracting long-term } \\
\text { deals with suppliers }\end{array}$ & 32.500 & 285.500 & -.841 & .400 & $.429^{a}$ \\
\hline
\end{tabular}

a. Rank related correction is not applied

Table 3. Rank value for groups if between them exists significant difference

\begin{tabular}{|c|c|c|c|c|}
\hline & negotiated & $\mathrm{N}$ & Middle ranks & Rank sum \\
\hline \multirow{2}{*}{$\begin{array}{c}\text { Determination of selling } \\
\text { price }\end{array}$} & .00 & 23 & 12.89 & 296.50 \\
\cline { 2 - 5 } & $1.00 /$ negotiated & 4 & 20.38 & 81.50 \\
\cline { 2 - 5 } & Total & 27 & & \\
\hline $\begin{array}{c}\text { Deciding on internal or } \\
\text { external selling and } \\
\text { purchase }\end{array}$ & .00 & 22 & 12.41 & 273.00 \\
\cline { 2 - 5 } & 1.00 & 4 & 19.50 & 78.00 \\
\cline { 2 - 5 } & Total & 26 & & \\
\hline
\end{tabular}

Table 4. Nonparametric Mann-Whitney test of differences in the degree of divisional management autonomy regarding implementation of market based TP model

\begin{tabular}{|c|c|c|c|c|c|}
\hline Market based & $\begin{array}{c}\text { Mann-Whitney } \\
\text { U }\end{array}$ & Wilcoxon W & Z & $\begin{array}{l}\text { Asymptotic } \\
\text { significance } \\
(2 w a y-p)\end{array}$ & $\begin{array}{c}\text { Exact } \\
\text { significance } \\
{\left[2^{*}(1-\text { way }\right.} \\
\text { significance/p)] }\end{array}$ \\
\hline $\begin{array}{c}\text { Determination of selling } \\
\text { price }\end{array}$ & 59.000 & 249.000 & -.926 & .354 & $.389^{a}$ \\
\hline $\begin{array}{c}\text { Determination of } \\
\text { production and sales } \\
\text { volume }\end{array}$ & 63.000 & 99.000 & -.529 & .597 & $.644^{a}$ \\
\hline Capital budgeting & 63.000 & 99.000 & -.513 & .608 & $.644^{a}$ \\
\hline $\begin{array}{l}\text { Deciding on internal or } \\
\text { external selling and } \\
\text { purchase }\end{array}$ & 51.000 & 222.000 & -1.203 & .229 & $.261^{a}$ \\
\hline Short-term borrowing & 68.500 & 104.500 & -.201 & .840 & $.849^{a}$ \\
\hline Long-term borrowing & 53.000 & 224.000 & -1.105 & .269 & $.311^{a}$ \\
\hline $\begin{array}{l}\text { Development of new } \\
\text { products and services }\end{array}$ & 69.500 & 240.500 & -.142 & .887 & $.892^{a}$ \\
\hline $\begin{array}{l}\text { Contracting long-term } \\
\text { deals with suppliers }\end{array}$ & 60.500 & 96.500 & -.658 & .511 & $.531^{a}$ \\
\hline
\end{tabular}

a. Rank related correction is not applied 
Table 5. Nonparametric Mann-Whitney test of differences in the degree of divisional management autonomy regarding implementation of cost based TP model

\begin{tabular}{|c|c|c|c|c|c|}
\hline Cost based & $\begin{array}{c}\text { Mann-Whitney } \\
U\end{array}$ & Wilcoxon W & $z$ & $\begin{array}{l}\text { Asymptotic } \\
\text { significance } \\
\text { (2way-p) }\end{array}$ & $\begin{array}{c}\text { Exact } \\
\text { significance } \\
{\left[2^{*}(1-\text { way }\right.} \\
\text { significance/p) }]\end{array}$ \\
\hline $\begin{array}{c}\text { Determination of selling } \\
\text { price }\end{array}$ & 78.500 & 183.500 & -.622 & .534 & $.550^{\mathrm{a}}$ \\
\hline $\begin{array}{c}\text { Determination of } \\
\text { production and sales } \\
\text { volume }\end{array}$ & 61.000 & 166.000 & -1.251 & .211 & $.252^{a}$ \\
\hline Capital budgeting & 68.500 & 173.500 & -.817 & .414 & $.432^{\mathrm{a}}$ \\
\hline $\begin{array}{l}\text { Deciding on internal or } \\
\text { external selling and } \\
\text { purchase }\end{array}$ & 77.000 & 155.000 & -.371 & .710 & $.742^{a}$ \\
\hline Short-term borrowing & 43.000 & 148.000 & -2.185 & .029 & $.036^{\mathrm{a}}$ \\
\hline Long-term borrowing & 69.000 & 174.000 & -.808 & .419 & $.462^{a}$ \\
\hline $\begin{array}{l}\text { Development of new } \\
\text { products and services }\end{array}$ & 83.000 & 188.000 & -.052 & .958 & $.980^{\mathrm{a}}$ \\
\hline $\begin{array}{l}\text { Contracting long-term } \\
\text { deals with suppliers }\end{array}$ & 65.000 & 170.000 & -1.006 & .314 & $.347^{a}$ \\
\hline
\end{tabular}

a. Rank related correction is not applied

Table 6. Rank value for groups if between them exists significant difference

\begin{tabular}{|l|c|c|c|c|}
\hline & Cost based & $\mathrm{N}$ & Middle ranks & Rank sum \\
\hline Short-term borrowing & .00 & 12 & 16.92 & 203.00 \\
\cline { 2 - 5 } & 1.00 & 14 & 10.57 & 148.00 \\
\cline { 2 - 5 } & Total & 26 & & \\
\hline
\end{tabular}

\section{CONCLUSION}

Transfer prices affect the costs, revenues and profit of divisions participating in inter-divisional trade, which further affects motivation of the divisional management and their contribution to corporate goals and long-term profitability.

In the long-term the interest of the divisions but the company too, is the promotion of inter-divisional trade. Reduction and control of the sales division's costs and the increase in its efficiency, can offer lower prices to the buying division and increase its interest for purchasing from another division within a company. After setting the range in which the transfer price will be determined divisional manager should choose the easiest way for it, having in mind the impact of transfer pricing on the divisional profit. The chosen transfer pricing model should be easy to understand and implement but at the same time flexible to changes in the environment and the market. Implemented transfer pricing model does not exclude the possibility of applying another model in the future according to the changes in costs, supply, demand, competition and other factors. Considering that implemented transfer prices model has significant influence on the capital budgeting and allocation of resources by divisions, distribution of corporate profit, harmonization of divisional and corporate objectives, as well as internal reporting, responsibility accounting, decision making, motivation and compensation of divisional management, company's management should evaluate different transfer pricing models in terms of all these aspects and choose the most appropriate model.

Limitation of the research is small sample related to undeveloped responsibility accounting and segment reporting in the companies participated in the research, as well as uninformed employees in Finance, Accounting and Controlling in terms of characteristics of transfer prices models and their influence on divisional and corporate revenues, expenditures and profit. Additional obstacle is lack of incentives and bonuses for divisional management in some companies participated in the research.

These facts could explain why hypothesis is not confirmed, unlike similar research carried out earlier in developed countries. Future research should be based on a bigger sample and include more companies whose responsibility centres participate in selling and purchase transactions within a company and apply particular transfer pricing models in those transactions. 


\section{REFERENCES}

[1] Ćirić, J., Perović, V. and Nerandžić, B. (2010), "Harmonizacija finansijske $i$ perspektive učenja $i$ rasta $u$ cilju povećanja vrednosti multidivizionalnog preduzeća”, SM2010 - Strategijski menadžment i sistemi podrške odlučivanju u strategijskom menadžmentu,

[2] Ćirić, J. and Malinić, S. (2010), "Measuring the performance of business segments and divisional management", International Conference for Entrepreneurship, Innovation and Regional Development ICEIRD (3; Novi Sad; 2010), pp.128-133.

[3] Dean, J. (1955), "Decentralization and Intracompany Pricing", Harvard Business Review, Vol. 33, No. 4, pp.65-74.

[4] Drury, C., El-Shishini, H. (2005). Divisional Performance Measurement: An Examination of the Potential Explanatory Factors, Chartered Institute of Management Accountants, London, UK.

[5] Ernst \& Young, (2017). Operationalizing global transfer pricing Key steps for translating strategy into practice, available at: https://www.ey.com/Publication/vwLUAssets/EYoperationalizing-global-transfer-pricing/\$FILE/EYoperationalizing-global-transfer-pricing.pdf

[6] Harris, M., Kriebel, C.H. and Raviv, A. (1982), "Asymmetric Information, Incentives and Intrafirm Resource Allocation", Management Science, Vol. 28, Jun, pp. 604-620.

[7] Hirshleifer, J. (1956), "On the Economics of Transfer Pricing", Journal of Business, 29, July, pp. 172-184.

[8] Horngreen, C.T., Datar, S.M., Foster, Rajan, M. and Ittner, C (2003), Cost Accounting: A Managerial Emphasis, 11 th.Ed. Prentice Hall Business Publishing.

[9] Kaplan, R.S. and Atkinson, A. (1998), Advanced Management Accounting, Prentice Hall.
[10] Malinić, D. (1999), Divizionalno računovodstvo Računovodstveno izveštavanje po profitnim $i$ investicionim centrima, Ekonomski fakultet, Beograd.

[11] Malinić, S. (2008), Upravljačko računovodstvo, Ekonomski fakultet, Kragujevac.

[12] Malinić, S. (2011). "Transferne cene kao faktor performansi preduzeća i poslovnih segmenata u kontekstu MSFI 8”, 15. Kongres računovođa i revizora Republike Srpske, Banja Vrućica.

[13] Martinson, O.B., McKee, T.C., (2001). Staying Out of Trouble with Transfer Pricing, The Journal of Corporate Accounting \& Finance, John Wiley \& Sons, Inc, pp. 39-47.

[14] Martini, J.T., (2008). Managerial versus financial transfer pricing - discussion paper, German Economic Association of Business Administration available at: http://www.geaba.de/wp-content/uploads/2017/07/DP-08-15.pdf

[15] OECD (2017). "Transfer Pricing Guidelines for Multinational Enterprises and Tax Administrations", available at: http://www.oecd.org/tax/transfer-pricing/oecd-transfer-pricingquidelines-for-multinational-enterprises-and-tax-administrations20769717.htm (accessed: 7 November 2018).

[16] Ronen, J., McKinney, G. (1970), "Transfer Pricing for Divisional Autonomy", Journal of Accounting Research, Spring 1970, pp. 99-113.

[17] Seal, W., Garrison, R.H., Noreen, E., (2006), Management Accounting, The McGraw-Hill Education.

[18] Shi, Y., Kwak, W., Lee, H., (1998). OptimalTrade-offs ofMultiple Factors in Transfer Pricing Problems, Journal of Multi-Cirteria Decision and Analysis, 7, pp. 98-108.

[19] Shim, J.K. and Siegel J.G. (2000), Modern Cost Management and Analysis, 2nd. Ed.Barron's Business Library, USA.

\title{
Uticaj decentralizovanog poslovnog odlučivanja na izbor modela transfernih cena u multidivizionom preduzeću
}

\author{
Jelena Demko-Rihter
}

Primljen (19.12.2018.); Recenziran (30.01.2019.); Prihvaćen (19.02.2019.)

\begin{abstract}
Abstrakt
Transferne cene se primenjuju u kupoprodajnim transakcijama između poslovnih segmenata ili divizija unutar preduzeća. Poreski $i$ upravljački aspekt transfernih cena su najčešće zastupljeni u literaturi i praksi. Fokus istraživanja u ovom radu je odnos između stepena autonomije divizionih menadžera prilikom poslovnog odlučivanja i načina utvrđivanja transfernih cena u kupoprodajnim transakcijama između divizija preduzeća. Cilj ovog rada je da predstavi problem transfernih cena i da objasni kako decentralizovano poslovno odlučivanje kroz sistem transfernih cena utiče na kratkoročne i dugoročne divizione i korporativne performanse. Istraživanje je sprovedeno na malom uzorku multidivizionih preduzeća koja posluju u Srbiji. Glavna hipoteza "Stepen autonomije divizionog menadžmenta prilikom poslovnog odlučivanja utiče na izbor modela transfernih cena u kupoprodajnim transakcijama između divizija u okviru preduzeća” nije potvrđena, za razliku od rezultata sličnih istraživanja sprovedenih ranije u razvijenim ekonomijama. U ovom istraživanju koriste se Spearmanov koeficijent korelacije ranga i Phi koeficijent, kao i ne parametarski Mann Whitney test.
\end{abstract}

Ključne reči: autonomija, odlučivanje, divizije, performanse, transferne cene 